Jurnal At-Tibyan: Jurnal Ilmu Alqur'an dan Tafsir

Volume 5 No. 2, Desember 2020 (h.152-170)

P ISSN 2442-594X | E ISSN 2579-5708

http://journal.iainlangsa.ac.id/index.php/tibyan

\title{
TAFSIRWEB: DIGITALIZATION OF QUR'ANIC INTERPRETATION AND DEMOCRATIZATION OF RELIGIOUS SOURCES IN INDONESIA
}

\author{
Achmad Rifai \\ Universitas Islam Negeri Sunan Kalijaga Yogyakarta, Indonesia \\ acharrifai@gmail.com \\ DOI 10.32505/jurnal at-tibyan.v5i2.1640

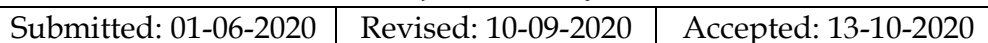

\begin{abstract}
:
The presence of the internet as a sign of the emergence of new media also creates a new medium in the interpretation of the al-Qur'an. This phenomenon is interesting to examine in order to complement the study of the interpretation of the al-Qur'an that existed before its appearance in new media. In examining this topic, which is related to the interpretation of the alQur'an on the tafsirweb.com website, the author uses a textual method by adopting a content analysis model. There are two things that are the results of this research, namely the digitization of interpretation to become the central spirit in tafsirweb.com, and the translation of tafsir books that leads to the democratization of religious sources. This is the contribution of this determination to fill in the gaps that scholars have neglected in examining the interpretation of the al-Qur'an.
\end{abstract}

Keywords: Tafsirweb, Digitalization, New Media, Internet and Qur'anic interpretation

\begin{abstract}
Abstrak:
Hadirnya internet sebagai pertanda munculnya media baru juga melahirkan medium baru dalam penafsiran al-Qur'an. Fenomena ini menarik untuk ditelaah guna melengkapi kajian atas penafsiran al-Qur'an yang telah ada sebelum kemunculannya pada media baru. Dalam menelaah topik ini, yakni terkait penafsiran al-Qur'an pada situs web tafsirweb.com, penulis menggunakan metode tekstual dengan mengadopsi model analisis isi (content analysis). Terdapat dua hal yang menjadi hasil dari penelitian ini, yakni digitalisasi tafsir menjadi menjadi ruh sentral dalam tafsirweb.com dan penerjemaahan terhadap kitab-kitab tafsir mengarah pada adanya demokratisasi atas sumber keagamaan. Hal ini lah yang menjadi sumbangsih penetian ini untuk mengisi celah yang diabaikan para sarjana dalam meneliti penafsiran al-Qur'an.
\end{abstract}

Kata Kunci: Media Baru, Internet dan Tafsir al-Qur'an

Hak Cipta @ 2020. Dimiliki oleh Penulis, dipublikasikan oleh Jurnal At-Tibyan: Jurnal Ilmu Alqur'an dan Tafsir. Artikel dengan akses terbuka. Lisenci: CC-BY

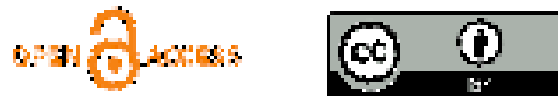




\section{Pendahuluan}

Kajian terhadap studi tafsir al-Qur'an selama ini masih kurang memberi perhatian yang cukup atas perkembangan media baru, yakni dengan ditandai dengan hadirnya internet. Padahal penetrasi internet dalam dunia kontemporer telah memunculkan apa yang oleh Prensky, sebagaimana dikutip Moch Fakhruroji, sebut sebagai "digital natives", yakni orang yang lahir dan besar dengan teknologi digital. ${ }^{1}$ Memang beberapa sarjana telah mencoba mengulasnya. Namun kebanyakan terjebak pada penafsiran seseorang yang muncul dalam dunia digital. ${ }^{2}$ Padahal selain hal tersebut, terdapat juga hasil penafsiran ulama klasik yang muncul dalam bentuk digital. Hal ini lah yang kurang — untuk tidak mengatakan luput — dari perhatian para sarjana. Selain itu, kajian tafsir di era munculnya media baru juga kebanyakan memusatkan pada media sosial berupa facebook maupun youtube. Adapun situs web belum mendapat kajian yang memadai. Padahal bila dibandingkan facebook maupun youtube, situs web lebih sering dan mudah diakses. Lebih lanjut, situs web juga mampu menyampaikan kajian secara tertulis secara lebih leluasa tanpa dibatasi oleh jumlah karakter sebagaimana yang berlaku pada media sosial lainnya.

Penelitian tafsir dalam medium situs web ini penting guna dapat melengkapi kajian penafsiran yang telah ada untuk dapat melihat secara utuh perkambangan penafsiran Alquran khusunya di era modern. Terlebih lagi Asosiasi Penyelenggara Jasa Internet Indonesia (APJII) merilis hasil surveinya yang dilakukan pada tahun 2018 secara nasional sebanyak 171, 17 juta penduduk menjadi pengguna internet, atau sekitar $64,8 \%$ dari persentase jumlah populasi penduduk Indonesia. Angka tersebut naik sekitar 30 juta pengguna bila dibandingkan dengan hasil survei pada tahun 2017 oleh lembaga yang sama. ${ }^{3}$ Data tersebut menggambarkan masifnya laju pertumbuhan pengguna internet di Indonesia. Hal ini lah yang kemudian memunculkan banyaknya kajian keislaman yang tersedia dalam dunia maya, tidak terkecuali dengan tafsir AlQur'an. Oleh sebab itu, penulis menelaah tafsir yang berkembang pada laman web tafsirweb.com. Web ini merupakan salah satu laman situs yang kerap kali dikunjungi oleh para pengguna internet di Indonesia. Tercatat situs tafsirweb.com telah dikunjungi sebanyak 3,99 juta pengunjung dengan 96,23 \% berasal dari negara Indonesia. Hal lainnya, tafsirweb.com adalah situs web keislaman yang secara khusus membahas dan menghadirkan tafsir al-Qur'an. Fokus utamanya terdiri dari dua hal. Pertama untuk menjawab tentang pola tafsir dalam situs web, apakah digitalisasi tafsir atau justru tafsir digital. Kedua implikasi atas pola tafsir yang dikembangkan dalam situs web khususnya tafsirweb.com.

\footnotetext{
${ }^{1}$ Moch Fahrurroji, "Digitalizing Islamic Lectures: Islamic Apps and Religious Engagement in Contemporary Indonesia". Contemporary Islam 13 (2019):201-215. https://doi.org/10.1007/s11562-0180427-9.

${ }^{2}$ Fadhli Lukman, "Tafsir Sosial Media Di Indonesia," Nun : Jurnal Studi Alquran Dan Tafsir Di Nusantara 2 no. 2 (2016): 117-139. 10.32495/nun.v2i2.59.

${ }^{3}$ https://apjii.or.id/survei2018s, accessed April 14, 2020.
} 
Dalam kaitannya dengan kajian tafsir Al-Qur'an pada laman web, khususnya website, tidak dapat dilepaskan dari diskursus studi Al-Qur'an dan media baru. Tema tersebut telah banyak dikaji oleh para peneliti dengan beragam aspeknya, mulai terkait cara pembelajaran Al-Qur'an, ${ }^{4}$ persoalan Al-Qur'an digital, ${ }^{5}$ hingga tafsir Al-Qur'an di media sosial yang dilakukan oleh Wildan Imaduddin Muhammad ${ }^{6}$ dan Fadhli Lukman. ${ }^{7}$ Meski Lukman telah mengkaji tafsir dalam lanskap media baru, namun Lukman hanya terfokus pada media sosial facebook. Kajian hampir serupa juga dilakukan Nafisatuzzahro yang mengambil fokus pada kajian tafsir di youtube. ${ }^{8}$

Lebih lanjut, penelitian yang secara khusus menjadikan website sebagai objek kajian dalam melihat tafsir Al-Qur'an dilakukan oleh Anis Nuralvi, ${ }^{9}$ Millah Maryam as-Sa'idah, ${ }^{10}$ dan Muhammad Saifullah. ${ }^{11}$ Nuralvi hanya terfokus pada sumber, metode serta corak penafsiran dalam situs almanhaj.or.id. Hal yang sama juga dilakukan asSa'idah yang hanya berbeda dalam situs web yakni muslim.or.id. Adapun Saifullah terfokus pada website Nadirsyah Hosen. Beranjak dari penelitian terdahulu tersebut, menurut penulis terdapat aspek yang belum dilihat oleh para peneliti yakni digitalisasi tafsir dan demokratisasi atas teks keagaman. Padahal hal ini dapat dikatakan sangat penting guna melihat secara utuh penafsiran yang berkembang di era media baru ini khususnya pada situs-situs web. Oleh karena itu, kehadiran penelitian ini sangat penting guna mengisi celah tersebut.

Sementara itu, metode yang digunakan dalam penelitian ini bersumber pada data yang berasal dari situs web tafsirweb.com sebagai sumber utamanya. Penentuan terhadap situs ini sebagai objek penelitian didasarkan pada dua hal. Pertama, situs tafsirweb.com terfokus pada penyebaran tafsir Al-Qur'an pada website. Hal ini tentu sangat berbeda dengan situs keislaman lainnya yang juga mengandung tafsir AlQur'an, tetapi tidak hanya terfokus pada kajian tafsir. misalnya, nu.or.id,

\footnotetext{
${ }^{4}$ Aminudin Aminudin, Zamah Sari, and Setio Basuki, "Aplikasi Multimedia Interaktif Pada Pembelajaran Metode Tilawati Berbasis Web Responsive," JRST (Jurnal Riset Sains dan Teknologi) 3, no. 1 (2019): 1-7. 10.30595/jrst.v3i1.3964

${ }^{5}$ Mohammed Zakariah, Muhammed Khurram Khan, Omar Tayan, and Khaled Salah, "Digital Quran Computing: Review, Classification, and Trend Analysis" Arab J Sci Eng 42 (2017): 3077-3102. https://oi.org/10.1007/s13369-017-2415-4.; Amirul Ramzani Radzid et al., "Kerangka Tashih Mushaf Al-Qur'an Digital : Pendekatan Pengecaman Corak," Journal of Fatwa Management and Research (2018): 322-334.

${ }^{6}$ Wildan Imaduddin Muhammad, "Facebook Sebagai Media BaruTafsir Al-Qur'an Di Indonesia: Studi Atas Penafsiran Alquran Salman Harun," Maghza: Jurnal Ilmu Al-Qur'an dan Tafsir 2 no. 2 (2017): 69-80. https://doi.org/10.24090/maghza.v2i2.1570.

${ }^{7}$ Fadhli Lukman, "Tafsir Sosial Media Di Indonesia, 117-139.

${ }^{8}$ Nafisatuzzahro, “Tafsir Al-Qur'an Audio Visual Cyber Media: Kajian Terhadap Studi Al-Qur'an Dan Tafsir" (Tesis, UIN Sunan Kalijaga, 2016).

${ }^{9}$ Anis Nuralvi, "Metodologi Penafsiran Al-Qur'an Dalam Website Almanhaj.or.id Dan Website Nadirhosen.Net." (diploma, UIN Sunan Gunung Djati Bandung, 2018), accessed April 13, 2020, http://digilib.uinsgd.ac.id/12943/.

${ }^{10}$ Millah Maryam As-Sa'idah, "Tafsir Alquran dalam website Muslim.or.id: studi pada sumber, metode dan corak" (diploma, UIN Sunan Gunung Djati Bandung, 2018), accessed April 13, 2020, http://digilib.uinsgd.ac.id/14943/.

${ }^{11}$ Muhammad Saifullah, "Hermeneutika Al-Qur'an Viertual: Kajian Atas Penafsiran Alquran Nadirsyah Hosen Di Facebook, Twitter, Telegram, Dan Website” (Tesis, UIN Sunan Kalijaga, 2019).
} 
muhammadiyah.or.id, muslim.or.id, almanhaj.or.id, atau situs keislaman lain. Kedua, berdasarkan pada observasi penulis sampai pada tanggal 10 April 2020, menggunakan perangkat (tool) SimilarWeb, mendapati situs tafsirweb.com menempati ranking ke391 dari beberapa situs web yang ada di Indonesia. rangking tersebut memang terlihat rendah bila dibandingkan tribunnews.com, detik.com, dan kompas.com yang berada diurutan tiga besar. Namun bila dibandingkan dengan situs keislaman, peringkat tafsirweb.com terbilang cukup tinggi. Di mana situs tersebut hanya kalah dari nu.or.id yang berada pada peringkat ke-203.

Selanjutnya, dalam membaca data yang didapatkan, penulis menggunakan metode tekstual. Artinya fokus utama dalam analisis adalah teks tafsir yang terdapat dalam situs web tersebut. Hal ini senada dengan penjelasan Sharon Lockyer dalam buku yang dieditori oleh Lisa M. Given. Menurutnya metode tekstual adalah metode analisis data yang meneliti baik konten dan makna teks atau struktur dan wacana mereka. Teks, yang dapat berkisar dari surat kabar, program televisi, dan blog hingga arsitektur, mode, dan furnitur, didekonstruksi untuk memeriksa bagaimana mereka beroperasi, cara mereka dibangun, cara makna diproduksi, dan sifat dari semua itu. ${ }^{12}$ Pada akhirnya metode tektual yang menitikberatkan pada kajian teks akan mengadopsi model analisis isi (content analysis). ${ }^{13}$

Sementara itu, untuk mempermudah pengumpulan data, penulis menggunakan teknik yang dikemukakan oleh Matthew B. Miles dan A. Michael Huberman. Di mana menurut Miles dan Huberman analisis kualitatif terdiri dari: mereduksi data (data reduction), menyajikan data (data display), dan penarikan kesimpulan atau verifikasi (conclusion drawing/ verification). ${ }^{14}$ Tahap pertama yakni mereduksi data penulis gunakan untuk menggambarkan signifikansi data atas tema penelitian ini. Adapun data display penulis maksudkan untuk membaca data dalam kerangka teoretik. Selanjutnya conclusioan drawing merupakan puncak penelitian yakni menyimpulkan hasil interpretasi data yang diperoleh yang menghasilkan fokus utama dalam penelitian ini, yakni digitalisasi tafsir dan demokratisasi sumber keagamaan. Dua hal tersebut penting guna membaca perkembangan tafsir yang ada di internet.

\section{Tafsir: Makna, Metodologi dan Kedudukannya}

Sebagai pembahasan awal dalam tulisan ini, terlebih dahulu harus dipahami term tafsir dalam kaitannya dengan makna, metodologi serta kedudukannya. Secara etimologi, kata tafsir berasal dari bahasa Arab fassara-yufassiru-tafsiran berarti memeriksa, memperhatikan atau juga dapat bermakna penjelasan dan komentar (al-

\footnotetext{
${ }^{12}$ Sharon Lockyer, The Sage Encyclopedia of Qualitative Research Methods, ed. Lisa M. Given, vol. 1 dan 2 (California: Sage Publications, 2008), 866.

${ }^{13}$ Lockyer, 865.

14 Matthew B. Miles and A. Michael Huberman, Qualitative Data Analysis: An Expanded Sourcebook, ii. (Amerika Serikat: Sage Publications, n.d.), 10.
} 
ịdāh wa asy-syarḥ). ${ }^{15}$ Adapun secara istilah, Abū Ḥayyān sebagaimana dikutip alSuyūțī memahami tafsir sebagai ilmu yang membahas tentang cara pelafalan huruf, dalil-dalil, dan hukum-hukum serta makna-makna al-Qur'an. ${ }^{16}$ Pengertian serupa juga diberikan oleh Al-Zarkasyī yang memaknai tafsir sebagai ilmu yang digunakan untuk memahami al-Qur'an beserta makna, hukum dan hikmahnya. ${ }^{17}$ Definisi yang diberikan di atas pada hakikatnya menempatkan tafsir pada dua dimensi, yakni sebagai ilmu (proses) dan sebagai produk. Tafsir sebagai ilmu dipandang merupakan piranti untuk memahami ayat al-Qur'an. Sedangkan tafsir sebagai produk dapat dipahami sebagai hasil pemahaman atau penjelasan seseorang (interpreter) atas ayat al-Qur'an.

Dalam kaitannya tafsir sebagai ilmu, hal itu meniscayakan akan sebuah metodologi. Terkait hal ini terdapat dua istilah kunci yang harus dipahami, yaitu perbedaan antara metode tafsir dan metodologi tafsir. Secara mendasar dapat dipahami bahwa metode tafsir erat kaitannya dengan cara penafsiran. Dengan ungkapan lain, "metode tafsir merupakan kerangka atau kaidah yang digunakan dalam menafsirkan ayat-ayat al-Qur'an."18 Adapun metodologi dalam kajian tafsir mengandung arti ilmu yang membahas cara interpretasi. Terkait metodologi tafsir, menurut Wardani, setidaknya terdapat empat hal yang terkandung di dalamnya. ${ }^{19}$ Pertama, sumber. Bila merujuk pada sumber, metode penafsiran secara umum dapat dikelompokkan menjadi dua, yakni yang bersumber dari riwayat, baik al-Qur'an, Hadis, perkataan para sahabat Nabi maupun generasi tabi'in (tafsir bil ma'sür) dan yang bersumber dari ijtihad seorang mufassir (tafsir bir ra'y).

Kedua, validitas penafsiran. Terkait hal ini, erat kaitannya dengan 'ulūm al-tafsìr yang menjadi bagian tak terpisahkan dari 'ulūm al-qur'ān. Dalam dunia modern, validitas penafsiran ini telah berkembang cukup pesat. Misalnya untuk menyebut sebagian sebagai contoh, lahirnya teori double movement oleh Fazlurrahman, teori batas (nazhariyyat al-ḥadd) oleh Syahrur, dan hermeneutika resepsi oleh Farid Esack. Ketiga, teknik penafsiran. Bila dilihat dari aspek teknik atau cara penafsiran secara umum dapat dipetakan menjadi empat; tafs̄̄r at-tahlili, tafs̄ir al-ijmali, tafs̄̄r almaudlut, dan tafsīr al-Muqaran. Keempat, pendekatan dan corak. Terkait yang terakhir ini Quraish mengungkapkan setidaknya ada beberapa corak yang lazim dipahami selama ini, misalnya corak sastra bahasa, fiqih atau hukum, corak tasawuf, filsafat dan teologi, maupun tipologi dari penafsiran ilmiah. ${ }^{20}$

\footnotetext{
${ }^{15}$ A.W. Munawir, Al-Munawir: Kamus Arab-Indonesia, 14th ed. (Surabaya: Pustaka Progressif, 1997).

${ }^{16} J a l a l u d d i n$ as-Suyuti, Al-Itqān Fì 'Uhùm al-Qur'Ān, cet. 7. (Beirut: Dar al-Kotob al-Ilmiyah, 2019), 317.

${ }^{17} A$ s-Suyuti, 317

${ }^{18}$ Hujair A.H. Sanaky, "Metode Tafsir Perkembangan Metode Tafsir Mengikuti Warna atau Corak Mufassirin]," Al-Mawarid 18 (February 12, 2008): 263-284. http://jurnal.uii.ac.id/ index.php/ JHI/article/ view/157.

${ }^{19}$ Wardani, Trend Perkembangan Pemikiran Kontemporer: Metodologi Tafsir al-Qur'an di Indonesia, (Banjarmasin: Kurnia Salam Semesta, 2017), 14.

${ }^{20}$ M Quraish Shihab, Membumikan Al-Qur'an (Bandung: Mizan, 1992), 72.
} 
Sementara itu, terkait dengan kedudukan tafsir tidak dapat dilepaskan fungsi dari tafsir itu sendiri. Lazim dipahami bahwa al-Qur'an yang menggunakan bahasa Arab tidak dapat dipahami oleh semua orang muslim, terlebih bagi seseorang yang tidak menguasai bahasa Arab. Dalam konteks ini, tafsir yang merupakan hasil penjelasan ulama terhadap ayat al-Qur'an juga menjadi sebuah perantara yang menghubungkan seseorang dengan makna yang dapat diakses dalam al-Qur'an. Pada intinya tafsir berfungsi menjelaskan ayat al-Quran sehingga ayat tersebut dapat bernilai pragmatis dalam kehidupan manusia. Tafsir dapat dipandang sebagai kunci representatif yang bertujuan untuk menyingkap tabir rahasia makna al-Quran. Sehingga, dalam konteks ini tafsir sebagai produk dianggap sebagai medium untuk mencapai maksud makna yang setidaknya mendekati dengan yang dikehendaki alQur'an. Hal ini sejalan dengan tujuan dasar dari al-Qur'an sendiri yakni sebagai petunjuk bagi umat manusia.

\section{Agama Digital: Sebuah Lensa Konseptual}

Dalam kaitannya untuk menggambarkan keterlibatan religius dengan Internet, maka penting untuk mendiskusikan terlebih dahulu kerangka konseptual tentang agama digital (digital religion). Sub-pembahasan ini sangat berhutang pada kajian yang telah dilakukan Campbell dalam buku yang dieditori olehnya, Digital Religion: Understanding Religious Practice in New Media Worlds. Campbell menggambarkan hal bertitik tolak dari pengimporan agama ke dalam perbatasan baru dunia maya, atau dunia yang tidak terlalu nyata yang diciptakan oleh teknologi realitas maya. ${ }^{21}$ Menurutnya, pada mulanya istilah yang digunakan untuk menggambarkan persinggungan agama dengan internet ini disebut agama-dunia maya (cyber-religion). Campbell juga mencatat bahwa istilah cyber-religion ini telah digunakan para sarjana kedalam berbagai makna. Misalnya Dawson menggunakannya untuk secara khusus mengidentifikasi "organisasi atau kelompok keagamaan yang hanya ada di dunia maya." Adapun Brasher menggunakan agama-dunia maya sebagai sebuah konsep yang luas, yang dapat merujuk pada "kehadiran organisasi keagamaan dan aktivitas keagamaan di dunia maya." Dengan demikian, konsep agama-dunia maya menyediakan cara untuk mengeksplorasi dan mempertanyakan asumsi dan pemahaman tradisional tentang agama saat ia terlibat dengan konteks budaya dan teknologi baru. Namun, menurut Campbell, karena agama-dunia maya merupakan konsep yang tidak berbentuk dan luas, dan fakta bahwa keterkaitannya dengan konsep dunia maya dan virtualitas sering menimbulkan asumsi bahwa itu didasarkan pada bentuk religiusitas yang tidak lengkap atau bentuk religiusitas yang palsu, berarti hal itu ada batasan kegunaannya. ${ }^{22}$

Dalam kaitannya dengan hal itu, menurut Campbell, untuk membedakan berbagai bentuk agama yang muncul secara online, Helland menawarkan kerangka

\footnotetext{
${ }^{21}$ Heidi A. Campbell, Digital Religion: Understanding Religious Practice in New Media Worlds, ed. Heidi A. Campbell (New York: Routledge, 2013), 2.

${ }^{22}$ Campbell, 2.
} 
konseptual lain. Dia mempresentasikan kategori "religion online" dan "online religion" untuk membedakan penggunaan religius Internet berdasarkan apakah informasi dan ritual sebagian besar didasarkan pada sumber dan praktik offline atau pada bentuk yang muncul dari praktik agama online. ${ }^{23}$ Kerangka konseptual ini yang kemudian membantu para sarjana sesudahnya, semisal Young, untuk membedakan jenis praktik yang mereka pelajari dan motivasi komunitas pengguna tertentu. Sehingga konsep pembingkaian ini memainkan peran penting dalam banyak studi tentang agama dan Internet, memungkinkan para sarjana untuk berbicara dalam istilah yang lebih konkret tentang ciri-ciri religiusitas berbasis Internet.

Perkembangan selanjutnya, menurut catatan Campbell, pada beberapa tahun berikutnya lahir istilah agama digital untuk menggambarkan praktik keagamaan secara online. Istilah ini telah menjadi tema dalam berbagai konferensi, penelitian maupun judul buku. Era ini yang oleh Campbell digambarkan sebagai bentuk penetrasi aktif dunia maya pada agama. Setidaknya ia sependapat dengan Stewart Hoover yang menyatakan bahwa studi tentang agama dan media baru telah berpindah dari sekadar mengeksplorasi "digitalisasi agama"_yang mempertimbangkan bagaimana media digital memaksa kelompok dan praktisi agama untuk beradaptasi dengan perubahan gagasan agama tradisi, otoritas, atau keaslian — untuk mempertimbangkan pada tingkat yang lebih dalam "kontribusi aktual 'digital' terhadap 'agama"'. ${ }^{24}$ Dengan kata lain, agama digital adalah agama yang dibentuk dengan cara baru melalui media dan budaya digital. Pada akhirnya, Campbell memaknai istilah agama digital sebagai ruang teknologi dan budaya yang muncul ketika berbicara terkait bagaimana bidang keagamaan online dan offline menjadi berbaur atau terintegrasi.

Dalam kaitannya dengan kajian penafsiran atas al-Qur'an dapat dipahami sebagai jembatan yang menghubungkan dan memperluas praktik dan ruang keagamaan online ke dalam konteks keagamaan offline, dan

Dengan demikian, penggabungan gagasan baru dan mapan tentang praktik keagamaan, termasuk di dalamnya kajian penafsiran al-Qur'an, menghendaki adanya "agama digital" yang ditanamkan oleh ciri-ciri budaya online dan agama tradisional.

\section{Karakteristik Media Baru dan Pengembangan Tafsir}

Media baru (new media) merupakan term yang digunakan untuk menggambarkan perkembangan cara dan sarana komunikasi antara seseorang dengan orang lainnya. Komunikasi merupakan aspek penting dalam kehidupan manusia. Di mana manusia selalu membutuhkan manusia lainnya, sehingga untuk menjembatani 'kebutuhan' antar manusia tersebut komunikasi memerankan fungsinya. Sehingga, laju perkembangan komunikasi berjalan searah dengan kebutuhan manusia. Artinya, manusia yang hidup secara komunal dalam wilayah tertentu dapat secara mudah melakukan komunikasi secara langsung. Pola komunikasi ini yang oleh Vin Crosbie, sebagaimana dikutip

\footnotetext{
${ }^{23}$ Campbell, 3 .

${ }^{24}$ Campbell, 4 .
} 
Mutohharun Jinan, sebagai komunikasi yang menggunakan media interpersonal atau one to one. ${ }^{25}$ Akan tetapi, pola komunikasi tersebut mendapat tantangan manakala kehidupan manusia tidak lagi tinggal dalam satu wilayah. Dalam konteks yang demikian, dibutuhkan sarana yang dapat menghubungkan komunikasi antar manusia yang secara factual. Hadirnya media massa semisal radio, televisi dan yang semisalnya mampu mengakomodir kebutuhan manusia tersebut. Namun, sejalan dengan pesatnya laju perkembangan ilmu pengetahuan dan teknologi yang memunculkan internet, komunikasi semakin mudah untuk dilakukan tanpa terhalang dengan batas teritorial dan geografis seseorang. Era ini lah yang disebut sebagai munculnya media baru atau new media.

Adapun terkait karakteristik dari media baru, terdapat dua unsur penting, yakni digital dan interaktif. ${ }^{26}$ Pada aspek digital mensyaratkan penggunaan atau penyimpanan data secara online. Adapun pada tataran interaktif menggambarkan bahwa media baru mampu menjembatani komunikasi yang tidak hanya satu arah, melainkan juga dapat digunakan secara interaktif. Aspek interaktif ini tentu yang menjadi pembeda antara media baru dengan media lama (media massa).

Berdasarkan karakteristik perkembangan cara komunikasi di atas, dapat dipahami bahwa perkembangan tafsir juga dapat disamakan. Di mana pada awalnya tafsir merupakan hasil tulis tangan dari para ulama ahli tafsir, mufassir (manuskrip). Masa ini dapat dianalogikan dengan pola komunikasi interpersonal yang sangat terbatas audiennya. Kemudian, hadirnya mesin cetak juga membuat perkembangan tafsir semakin massif. Pada era ini dapat disamakan dengan komunikasi melalui media massa. Selanjutnya, hadirnya internet membawa ruang yang berbeda dari era sebelumnya. Sejalan dengan karakteristik media baru, perkembangan tafsir pada masa ini juga berbentuk digital dan dapat dilakukan secara interaktif dan publik. Era ini membuat persebaran penafsiran berjalan lebih dinamis sejalan dengan laju perkembangan teknologi itu sendiri.

\section{Tafsir Web: Sketsa Singkat}

Sebagai basis pijakan metodologis, penulis akan menguraikan gambaran umum tafsir yang ada pada situs web tafsirweb.com. Pada laman situs tersebut selain terdapat tafsir juga berisi al-Qur'an dan terjemahannya. Terkait tafsir, situs web tafsirweb.com mempunyai dua klasifikasi, yakni tafsir berdasarkan topik dan tafsir berdasarkan serial. $^{27}$ Tafsir berdasarkan topik berisi kajian tafsir terhadap tema-tema tertentu misalnya ayat tentang riba, ayat tentang bersyukur, dan lain-lain. Dalam poin ini dapat disebut sebagai tafsìr al-maudlut. Jumlah yang terdapat pada tafsir terhadap topik ini berjumlah 82 kajian, yang secara umum dapat dikelompokkan kedalam ibadah dan

\footnotetext{
${ }^{25}$ Mutohharun Jinan, "Intervensi New Media dan Impersonalisasi Otoritas Keagamaan di Indonesia," Jurnal Komunikasi Islam 03 no. 02, (2013) : 321-348. https://doi.org/10.15642/jki.2013.3.2.\%25p

${ }^{26}$ Martin Lister, dkk., New Media: a Critical Introduction, (New York: Roudledge, 2009), 13.

27 "Halaman | Tafsirweb," diakses pada 13 April 2020, https://tafsirweb.com/halaman.
} 
akidah; syariah dan hukum; muamalah; ilmu pengetahuan; kisah; kesehatan; dakwah; serta adat.

Sementara itu, tafsir berdasarkan serial terdapat 42 seri. Adapun rinciannya sebagai berikut:

\begin{tabular}{|c|l|c|c|l|c|}
\hline NO & NAMA SURAT & AYAT & NO & NAMA SURAT & AYAT \\
\hline 1. & Al-Kahfi & $1-10$ & 22. & Al-Hujurat & $10-12$ \\
2. & Maryam & $1-11$ & 23. & Al-Fajr & $27-30$ \\
3. & Thaha & $1-5$ & 24. & Al-Jumuah & $9-10$ \\
4. & Yunus & $40-41$ & 25. & Al-Hasyr & $18-24$ \\
5. & Alimran & $26-27$ & 26. & Az-Zalzalah & $7-8$ \\
6. & Al-Mukminun & $12-14$ & 27. & Yusuf & $1-16$ \\
7. & Ath-Thalaq & $2-3$ & 28. & Thaha & $25-26$ \\
8. & Al-Baqarah & $1-5$ & 29. & Al-Hasyr & $22-24$ \\
9. & Al-Baqarahs & $1-10$ & 30. & An-Naml & $30-31$ \\
10. & Al-'Alaq & $1-5$ & 31. & Al-Isra & $26-27$ \\
11. & Al-Hasyr & $21-24$ & 32. & Al-Isra & $79-81$ \\
12. & Alimran & $190-191$ & 33. & Alimran & $38-39$ \\
13. & Al-Baqarah & $285-286$ & 34. & Al-Mukminun & $1-11$ \\
14. & At-Taubah & $128-129$ & 35. & Maryam & $2-11$ \\
15. & Al-Baqarah & $289-286$ & 36. & Al-Mukminun & $12-14$ \\
16. & Luqman & $13-14$ & 37. & Adz-Dzariyat & $56-58$ \\
17. & Al-Isra & $23-24$ & 38. & Al-Maidah & $51-54$ \\
18. & Al-Insyirah & $5-6$ & 39. & Al-Baqarah & $255-257$ \\
19. & An-Najm & $39-42$ & 40. & Yunus & $81-82$ \\
20. & Al-Maidah & $90-91$ & 41. & Al-Waqiah & $35-38$ \\
21. & Ar-Rum & $41-42$ & 42. & At-Taubah & $65-66$ \\
\hline
\end{tabular}

(Diolah dari sumber laman tafsirweb.com)

Data tersebut menunjukkan bahwa tafsir serial yang terdapat dalam situs web tafsirweb.com belum lengkap. Bahkan belum ada surat yang secara lengkap ditafsirkan. Padahal klaim dalam laman tersebut bahwa "kami menyediakan tafsir lengkap $30 \mathrm{Juz}$ yang dapat anda pilih dengan mudah." ${ }^{28}$ Namun meski demikian, nampaknya hal itu merupakan proses yang hingga saat ini terus berlangsung. Hal ini dapat dipahami dari ungkapan yang terdapat dalam laman situs tersebut "website sederhana yang sedang dalam proses pengembangan untuk menjadi pusat kumpulan tafsir al-Qur' an terlengkap di Indonesia." 29

\footnotetext{
28 "Halaman | Tafsirweb,"

29"Halaman | Tafsirweb,"
} 
Selain tafsir secara serial dan topik, dalam laman web tersebut juga tersedia serba-serbi al-Qur'an yang berisis 10 essay terkait dengan al-Qur'an, yaitu 1) keutamaan menbaca al-Qur'an; 2) Tadabbur adalah hal yang penting untuk diketahui dan diterapkan, bagaimana caranya?; 3) sembilan keutamaan al-Qur'an bagi pembacanya menurut hadis dan ayat al-Qur'an; 4) nama lain al-Qur'an; 5) urutan surat juz 30 al-Qur'an; 6) cara menghafal al-Qur'an: hal-hal yang harus diperhatikan; 7) apa itu idgham?; 8) mushaf adalah, apa?; 9) tentang ayat di dalam al-Qur'an; 10) al-Qur'an adalah kalam ilahi.

Server dari laman web tafsirweb.com beralamatkan di Jl. Kota Mas Indah NO. 63, Kecamatan Cimahi Tengah, Kota Cimahi, Provinsi Jawa Barat, Indonesia. ${ }^{30}$ Laman web ini pada dasarnya merupakan bentuk kumpulan dari tafsir-tafsir atas ayat alQur'an yang terdapat dalam berbagai kitab tafsir. Selanjutnya, demi memberikan kemudahan bagi khalayak umum untuk dapat mengakses tafsir al-Qur'an dalam kitab tafsir, yang kebanyakan ditulis menggunakan bahasa Arab, laman web ini menerjemahkannya kedalam bahasa Indonesia. Pola yang demikian dapat dimaknai sebagai bentuk negosiasi kajian tafsir dalam media baru, yakni pada satu sisi memberikan kemudahan untuk komunitas umum, tidak hanya bagi orang yang mampu memahaminya dari sumber aslinya (yakni bahasa Arab), namun pada sisi lain juga tidak meninggalkan otoritas keilmuan. Dalam kaitannya dengan hal ini pada laman tersebut tertulis "dalam penyusunan website ini kami mengambil sumber tafsir dari beberapa kitab pada ulama yang populer dan juga terpercaya agar dapat menghasilkan kualitas tafsir terbaik dan memberikan hasil paling akurat." ${ }^{31}$ Laman web tersebut juga tidak menuliskan teks tafsir para ulama yang dikutip dengan bahasa aslinya, yakni bahasa Arab, namun diterjemahkan kedalam bahasa Indonesia.

\section{Digitalisasi Tafsir dan Tafsir Digital}

Sebelum menguraikan lebih lanjut tentang digitalisasi tafsir dan tafsir digital, terlebih dahulu penulis menguraikan tentang kerangka konsepnya. Istilah digitalisasi tafsir dan tafsir digital penulis kembangkan dari konsep agama online (religion online) dan beragama online (online religion) yang dicetuskan Young. ${ }^{32}$ Dalam menjelaskan kedua istilah tersebut, Young menyatakan:

These are: (1) the provision of information about religion versus the opportunity for participation in religious activity; and (2) primary reference to offline, preexisting religious traditions versus primary reference to religious activities taking place online. ${ }^{33}$

Penjelasan Young tersebut dapat diidentifikasi bahwa religion online merujuk pada ketentuan informasi tentang agama dan referensi utama untuk tradisi keagamaan

\footnotetext{
30 "Halaman | Tafsirweb,"

31،"Halaman | Tafsirweb,"

${ }^{32}$ Glenn Young, "Reading and Praying Online: The Continuity of Religion Online and Online Religion in Internet Chistianity," in Religion Online: Finding Faith on the Internet, ed. Lorne L. Dawson dan Douglas E. Cowan (New York: Routledge, 2004), 93.

${ }^{33}$ Young, 93.
} 
yang sudah ada sebelumnya. Adapun online religion menunjukkan pada kesempatan untuk berpartisipasi dalam agama dan referensi utama untuk kegiatan keagamaan yang berlangsung online. Beranjak dari hal tersebut, menurut penulis religion online dapat disamakan dengan digitalisasi tafsir. Di mana digitalisasi tafsir menunjukkan teks tafsir sebagai tradisi yang sudah ada. Sehingga hal itu hanya sebagai bentuk menghadirkan informasi virtual di internet. Sedangkan tafsir digital juga memiliki basic-conceptual yang sama dengan online religion. Hal itu dapat dipahami bahwa tafsir digital menunjukkan kegiatan atau partisipasi penafsiran yang dilakukan secara digital.

Hadirnya internet sebagai media baru komunikasi di era modern memang mampu memunculkan space atau ruang baru dalam kajian keislaman, semisal tafsir al-Qur'an. Munculnya ruang baru dalam kerangka media baru ini telah mampu menawarkan sesuatu yang lebih sesuai dengan kebutuhan masyarakat modern. Dunia internet menawarkan sesuatu yang mudah diakses dan tidak membutuhkan ruang yang besar untuk menyimpannya karena semuanya bisa diakses dan disimpan dalam smartphone. Hal ini tentu berbeda dengan kajian tafsir yang terdapat dalam kutub at-tafsir yang sulit diakses baik karena medium bahasa yang digunakan maupun pencariannya serta membutuhkan ruang yang besar untuk menyimpannya karena berbentuk fisik.

Beranjak dari konseptual di atas, menurut penulis penafsiran yang tersedia dalam situs web tafsirweb.com dapat diklasifikasikan sebagai bentuk digitalisasi tafsir. Hal ini didasarkan pada fakta bahwa dalam situs web tersebut sama sekali tidak terdapat kegiatan atau partisipasi penafsiran yang dilakukan secara digital. Tafsir yang terdapat dalam laman situs tersebut, baik berdasarkan topik maupun berdasarkan serial hanya merupakan hasil terjemahan secara literal atas kitab-kitab tafsir. Bahkan penafsiran dalam web tersebut tidak ditemukan sama sekali komentar atas ayat al-Qur'an selain hasil terjemahan terhadap karya-karya tafsir yang telah ada. Dalam ungkapan lain, tafsir dalam situs tafsirweb.com hanya sebagai referensi utama untuk tradisi keagamaan yang sudah ada sebelumnya. Pola yang demikian sangat unik dalam kerangka tafsir pada situs web. Bila dibandingkan dengan situs web keislaman lain yang juga memiliki kajian tafsir, semisal nu.or.id, muhammadiyah.or.id, atau yang lainnya. Hal ini dapat dilihat misalnya ketika dalam web nu.or.id menafsirkan ayat kedua surah Al-Baqarah. Setelah mengutip berbagai pendapat ulama semisal AlQurthubi, Al-Baidhawi dan lainnya, kemudian dikatakan bahwa:

Kata "petunjuk" secara khusus diletakkan pada orang yang bertakwa karena mereka menerima petunjuk dan mengambil manfaat pada nash. Meskipun "petunjuk atau hidayah" itu bersifat umum untuk orang muslim dan nonmuslim dengan pertimbangan "hudan lin nas" atau sebagai petunjuk bagi manusia, tidak ada yang mengambil manfaat melalui perenungan kecuali orang membersihkan akalnya dari karat, menggunakannya untuk merenungkan ayat, mencermati mukjizat, dan mengerti kenabian. Pasalnya, ia seperti asupan gizi yang layak untuk menjaga kesehatan, dan mengerti kenabian. Pasalnya, ia seperti asupan gizi 
yang layak untuk menjaga kesehatan. Selagi tidak sehat, maka ia takkan dapat mendatangkan manfaat. ${ }^{34}$

Hal yang sama juga terjadi dalam situs web Muhammadiyah yang bisa diakses di muhammadiyah.or.id. Dalam laman web tersebut hanya terdapat tafsir secara tematik dan tidak seperti yang ada pada tafsirweb.com. Penafsiran dalam situs web Muhammadiyah lebih mengarah pada produksi penafsiran ketimbang penerjemahan terhadap penafsiran yang sudah ada. Misalnya ketika menafsirkan dengan tema "Ulama dan Umara dalam Perspektif al-Qur'an" dinyatakan bahwa:

Menghadapi berbagai perubahan besar yang cepat dan bersifat majemuk dalam masyarakat dunia serta menghadapi pergeseran tata nilai yang mengaburkan antara yang benar dan yang salah, antara yang baik dan yang buruk, para ulama niscaya mengemban fungsi: (1) basyiran, memberi kabar gembira dengan memberikan harapan serta perspektif baru bagi upaya pembangunan; (2) nadziran, memberikan kesadaran kritis kepada masyarakat agar mereka mampu mengembangkan penalaran yang kritis terhadap determinisme ideologis maupun teknologis dengan menyadari permasalahan dan potensi yang mereka miliki untuk mampu mengubah nasibnya sendiri; (3) da'iyan ilal haqq, memanggil kepada kebenaran hakiki yang kadang-kadang telah dikaburkan oleh propaganda maupun pendapat umum; (4) sirajan muniran, memberikan terang iman dan pencerahan akal budi. Semua itu niscaya dilakukan ulama dengan menampilkan Islam yang hakiki sebagai rahmatan lil 'alamin. ${ }^{35}$

Berdasar pada contoh di atas, terlihat jelas dalam situs web nu.or.id dan muhammadiyah.or.id secara aktif memproduksi makna dalam penafsiran. Tentu hal ini berbeda dengan yang terdapat pada laman tafsirweb.com yang hanya menerjemahkan penafsiran para ulama yang dijadikan sumber tanpa ada produksi interpretasi yang baru. Dengan demikian, tafsir dalam situs-situs nu.or.id dan muhammadiyah.or.id dapat dikategorikan sebagai aktifitas penafsiran secara digital. Hal ini berbeda dengan laman web tafsirweb.com yang dalam kajian tafsir tidak dapat digolongkan kedalam tafsir digital melainkan masuk dalam istilah digitalisasi tafsir. Meski demikian pada aspek pembelajaran al-Qur'an yang meliputi cara membacanya, laman web ini dapat dikelompokkan kedalam online religion sebagaimana konsep Young di atas. Dalam situs web tersebut, pengguna internet dapat berpartisipasi secara langsung untuk belajar membaca al-Qur'an. Sehingga dalam tataran ini, tafsirweb.com menyediakan kesempatan untuk berpartisipasi dalam agama dan menjadi referensi utama untuk kegiatan keagamaan yang berlangsung secara online.

Selain perbedaan mendasar antara digitalisasi tafsir dengan tafsir digital sebagaimana yang telah diuraikan di bagian atas, poin penting yang menjadi pembeda di antara keduanya adalah kemudahan menghadirkan otoritas keilmuan yang erat

\footnotetext{
34،"Tafsir Surat Al-Baqarah Ayat 2," last modified January 31, 2020, accessed October 6, 2020, https://islam.nu.or.id/post/read/116041/tafsir-surat-al-baqarah-ayat-2.

35 "Halaman 5 - Tafsir Al-Qur' an Muhammadiyah," Halaman 5 - Tafsir Al-Qur'an' Muhammadiyah, accessed October 7, 2020, http://m.muhammadiyah.or.id/id/5-content-190-det-tafsir-alquran.html.
} 
kaitannya dengan kompetensi penafsir. Artinya, bila kajian tafsir berorientasi pada tafsir digital, maka otoritas tafsir yang disampaikan atau dihadirkan mungkin masih menimbulkan perdebataan. Hal ini karena Nabi Muhammad saw. Pernah menyebutkan dalam hadisnya bahwa seseorang tidak boleh berkomentar atau menafsirkan al-Qur'an hanya berdasarkan akalnya sendiri tanpa melibatkan keilmuan al-Qur'an yang memadai. ${ }^{36}$ Problem otoritas ini tentu tidak akan terjadi ketika terjadinya proses digitalisasi tafsir. Hal ini sejalan dengan Intisar A Rabb dan Sharon Tai yang menyatakan bahwa "the online portal seeks to fulfill a variety of scholarly, library, and user-search needs. In particular, it aims to integrate physical workspaces into a robust digital arena." ${ }^{37}$ Artinya, bentuk digitalisasi sumber keagamaan yang dilakukan portal online dapat dipandang sebagai bentuk pengintegrasian ruang fisik kedalam arena digital.

Kitab-kitab tafsir yang digunakan dalam laman web tafsirweb.com secara umum telah diakui otoritas dan kredibelitasnya. Oleh karena itu, persoalan otoritas dalam penafsiran tidak lagi menjadi perdebatan dalam web ini.

\section{Demokratisasi Teks: Penerjemahan atas Kitab Tafsir}

Sebagaimana telah disinggung di atas, bahwa tafsir dalam situs web tafsirweb.com, baik tafsir berdasarkan topik maupun tafsir berdasarkan serial, murni hanya berupa terjemahan secara literal atas kitab-kitab tafsir. Walaupun demikian, penerjemahan terhadap teks tidak dapat dilepaskan dari subjektifitas penerjemah. Hal itu sejalan dengan apa yang diungkapkan oleh Nur Ichwan dalam penelitiannya terhadap penerjemahan al-Qur'an oleh Kementerian Agama. ${ }^{38}$ Hal yang sama juga diungkap oleh Munirul Ikhwan terkait pengaruh ideologi dalam penerjemahkan Alquran. ${ }^{39}$ Oleh karena itu, terjemahan secara literal harus dipahami sebagai pengalihbahasaan yang merepresentasikan makna kata demi kata.

Sebelum menguraikan hal ini lebih lanjut, terlebih dahulu penulis akan paparkan karya-karya kitab tafsir yang menjadi sumber dalam situs web tersebut, yaitu: alQur'an dan Terjemahnya; Tafsir Kemenag RI; at-Tafsīr al-Muyassar yang merupakan karya perkumpulan ulama dengan Shalih 'Ali Syaikh, Menteri Urusan Islam, Dakwah dan Penyuluhan Saudi Arabia sebagai pengawasnya; al-Mukhtașar fi at-Tafs̄ir yang diterbitkan oleh Markaz Tafsīr lid-Dirāsāt al-Quraniyah, Riyadh; Tafsīr Juz' 'Amm Syaikh Shalih al-Fauzan; Zubdah at-Tafsir karya Muhammad Sulaiman al-Asyqar; at-

\footnotetext{
${ }^{36}$ Muhammad bin Umar Nawawi, Marāh Labīd li-Kasyf Ma'nā al-Qur'ān al-Maj̄o, Juz 1 (Beirut: Dar al-Kutub al-'Ilmiyah, 1997), 5.

37،"Digital Islamic Law: Purpose and Prospects - ProQuest," accessed October 6, 2020, https://search. proquest.com/openview/0cef2e8eef07d6864c6bd48991e0729a/1?pq-origsite=gscholar\&cbl=48662.

${ }^{38}$ Moch Nur Ichwan, Negara, Kitab Suci, Dan Politik: Terjemah Resmi al-Qur'an Di Indonesia, ed. Henri Chambert-Loir, Sadur: Sejarah Terjemahan di Indonesia dan Malaysia (Jakarta: Kepustakaan Populer Gramedia \& Ecole Française d'Extrême-Orient, 2009).

${ }^{39}$ Munirul Ikhwan, "Challenging the State: Exegetical Translation in Opposition to the Official Religious Discourse of the Indonesian State," Journal of Qur'anic Studies 17 no.3 (2015): 121-157. https://www.euppublishing.com/doi/abs/10.3366/jqs.2015.0214.
} 
Tafsìr al-Wajiz yang merupakan karya Sarjana Muslim asal Siria, Wahbah az-Zuhaili; dan Hidāyah al-Insān bi-Tafs̄ir al-Qur'ān karya Marwan Hadi.

Sebagai bukti bahwa situs web tafsirweb.com hanya menerjemahkan secara literal karya-karya kitab tafsir, di bawah ini akan penulis berikan contohnya. Misalnya tafsir yang membahas persoalan hijab. Dalam situs tersebut hanya menerjemahkan penafsiran al-Qur'an ayat 59 surat al-Ahzab yang termaktub dalam kitab tafsir atTafs̄ir al-Muyassar, al-Mukhtașar fi at-Tafsìr, Zubdah at-Tafsìr dan at-Tafsìr al-Waj̄̇.

\section{Dalam al-Mukhtașar fi at-Tafsìr:}

Wahai Nabi! Katakanlah kepada istri-istrimu, kepada anak-anak perempuanmu dan kepada istri-istri kaum mukminin, agar mereka memanjangkan jilbab yang mereka pakai ke seluruh tubuh mereka sehingga aurat mereka tidak tersingkap di hadapan lelaki asing. Yang demikian ini agar mereka lebih mudah dikenali sebagai orang merdeka, sehingga tidak ada orang yang mengganggu mereka sebagaimana gangguan yang biasa dialami oleh hamba sahaya perempuan. Dan Allah Maha Pengampun atas dosa-dosa para hamba-Nya yang bertobat kepada-Nya, lagi Maha Penyayang kepada mereka. ${ }^{40}$

\section{Dalam at-Tafsìr al-Muyassar:}

Tafsir Ayat Tentang Hijab menjelaskan sebagai berikut: Wahai Nabi, ucapkankan lah kepada istri-istrimu, anak-anak perempuanmu dan wanitawanita kaum Mukminin agar mereka menjulurkan kain-kain mereka dari kepala dan wajah mereka untuk menutupi wajah mereka, kepala dan dada mereka. Hal itu lebih dekat kepada keterjagaan dan perlindungan sehingga mereka tidak beresiko diganggu atau dijahili. Allah Maha Pengampun lagi Maha Penyayang di mana Dia mengampuni apa yang telah berlalu dari kalian, Dia menyayangi kalian dengan apa yang Dia jelaskan, mana yang halal dan mana yang haram. ${ }^{41}$

\section{Dalam at-Tafsīr al-Wajiz:}

Ayat tentang hijab/penutup ini, wahai Nabi katakanlah kepada para istri dan puterimmu, juga kepada para mukmin perempuan apabila mereka keluar dari rumah: Agar mereka melonggarkan dan menggeraikan sebagian pakaian mereka di atas mereka yang dapat menutupi seluruh badan mereka. Adapun jilbab adalah pakaian luar yang dapat menutupi seluruh badan. Maksudnya adalah untuk menggeraikan sebagaian pakaian yang dapat menutupi wajah selain mata. Ini dimaksudkan sebagai ciri bahwa mereka adalah perempuan yang merdeka bukan sorang hamba sahaya. Dengan begitu, orang fasik tidak akan mengganggu mereka. Sesungguhnya Allah Maha mengampuni terhadap pendahulu mereka yang telah meninggalkan penutup badan, dan Maha Pengasih kepada hamba-Nya. Abu Malik berkata: Dulu para mukmin

\footnotetext{
40،"145300.Pdf," n.d., accessed April 14, 2020, https://tafsirweb.com/wp-content/uploads/Kitab-Tafsir/ 04-Mukhtashar-Fii-Tafsiir-Nukhbah/145300.pdf.

41،Ar_Altafsir_Almaysir.Pdf," n.d., accessed April 14, 2020, https://tafsirweb.com/wp-content/ uploads/Kitab-Tafsir/03-Tafsir-Muyassar-Nukhbah/ar_Altafsir_Almaysir.pdf.
} 
perempuan keluar malam hari untuk memenuhi hajat mereka, kemudian orangorang munafik mengganggu dan menyakiti mereka. Kemudian turunlah ayat ini. $^{42}$

Dalam Zubdah at-Tafsir:

(Hendaklah mereka mengulurkan jilbabnya) Makna jilbab merupakan pakaian yang menutup seluruh tubuh perempuan. Dan makna mengulurkannya adalah dengan menjulurkannya sampai menutupi perhiasannya yang Allah perintahkan untuk ditutupi. ذِلِّ (Yang demikian itu) Yakni mengulurkan jilbab itu. أَدْنَّ أَنْ يُعْرَفْنَ (supaya mereka lebih mudah untuk dikenal) Yakni agar mudah dikenali oleh orang yang melihat mereka sehingga dapat terbedakan dari para budak wanita, dan menjadi jelas bagi orang bahwa mereka adalah para wanita merdeka yang suci dan menjaga kehormatan.

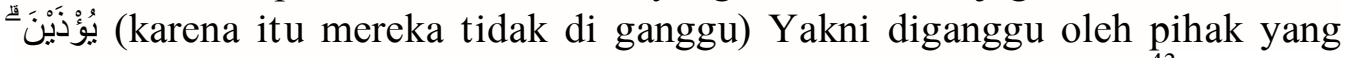
dalam hatinya terdapat penyakit dengan mencoba menodai mereka. ${ }^{43}$

Hal yang sama juga berlaku dalam tafsir berdasarkan serial. Tafsir yang disajikan dalam situs web tafsirweb.com hanya berupa terjemahan literal terhadap kitab tafsir. Dalam kaitannya dengan hal ini, penyusun website tersebut pada laman tafsirweb.com secara jelas menyatakan bahwa "kami mengambil sumber tafsir dari beberapa kitab pada ulama yang populer dan juga terpercaya agar dapat menghasilkan kualitas tafsir terbaik dan memberikan hasil paling akurat." ${ }^{24}$ Pola yang demikian dapat dimaknai sebagai bentuk negosiasi kajian tafsir dalam media baru, yakni pada satu sisi memberikan kemudahan untuk komunitas umum, tidak hanya bagi orang yang mampu memahaminya dari sumber aslinya (yakni bahasa Arab), namun pada sisi lain juga tidak meninggalkan otoritas keilmuan, semisal yang berkaitan dengan kapasitas seorang penafsir.

Dalam kaitannya dengan otoritas keagamaan pada cyberspace, Pauline Hope Chong mencatat adanya dua aliran utama. Pertama, lebih berakar pada penekanan dalam Internet sebagai ruang yang terdesentralisasi dan bebas. Konseptualisasi yang dominan adalah bentuk-bentuk otoritas keagamaan diubah oleh teknologi digital, yang dianggap mengganggu dan menggantikan doktrin dan domain kepercayaan tradisional, yang sering kali tertanam dalam bentuk komunikasi hierarkis. Kedua, penetrasi otoritas lama pada media baru. Internet mungkin, sampai batas tertentu, telah memfasilitasi perubahan dalam struktur pribadi dan organisasi yang digunakan oleh para pemimpin agama (pemilik otoritas). Tetapi, praktik aktif dan akomodatif oleh beberapa ulama, terkait dengan keterlibatan mereka dengan media digital, memungkinkan mereka untuk mendapatkan kembali legitimasi dan kepercayaan yang

\footnotetext{
42،AAl-Wajiz-Wahbah-Zuhaili.Pdf,” n.d., accessed April 14, 2020, https://tafsirweb.com/wp-content/ uploads/Kitab-Tafsir/14-al-Wajiz-Wahbah-Zuhaili/al-Wajiz-Wahbah-Zuhaili.pdf.

43،"Ar_Zobdat_altafser.pdf," n.d., accessed April 14, 2020, https://tafsirweb.com/wp-content/uploads/ Kitab-Tafsir/06-Zubdat-at-Tafsir/ar Zobdat altafser.pdf.

44،"Halaman Tafsirweb," diakses pada 13 April 2020, https://tafsirweb.com/halaman.
} 
diperlukan untuk beroperasi di ranah keagamaan. ${ }^{45}$ Dua klasifikasi implikasi internet atas otoritas keagamaan ini memudahkan untuk melihat situs tafsirweb.com dalam kaitannya dengan kontestasi otoritas keagamaan di ruang digital.

Penerjemahan karya tafsir yang dipublikasikan dalam situs web tafsirweb.com pada hakikatnya membuka diskusi lebih dalam terkait demokratisasi sumber keagamaan. Lazim diketahui bahwa sumber keagamaan yang menggunakan bahasa Arab hanya dapat diakses oleh para elit agama yang memiliki kemampuan (ulama). Dalam konteks demikian, lahir lah otoritas keagaman. Namun, ketika karya tafsir tersebut telah diterjemahkan, maka hal itu juga telah memudahkan banyak orang untuk mengakses secara langsung terkait pengetahuan keagamaan. Implikasinya, sumber keagamaan tidak lagi dimonopoli oleh kalangan tertentu. ${ }^{46}$ Lebih lanjut, penggunaan situs web untuk menyampaikannya juga semakin menguatkan adanya kontestasi otoritas keagamaan. Pola yang demikian sangat lazim diketemukan pada media baru. Di mana kehadiran media baru mampu melahirkan ruang baru (new space) yang dapat menjadi tantangan sekaligus intervensi atas otoritas keagamaan yang telah mapan (tradisional). Hal ini senada dengan hasil penelitian Fadli Lukman yang mengungkap bahwa "digital hermeneutics menandai kesetaraan dan demokratisasi dalam partisipasi terhadap aktivitas hermeneutis al-Qur'an dan tantangan terhadap otoritas."

\section{Penutup}

Berdasarkan pada hasil pembahasan di atas, dapat disimpulkan bahwa situs web tafsirweb.com memiliki keunikan dalam pengembangan tafsir dalam medium media baru bila dibandingkan dengan situs keislaman lainnya. Setidaknya terdapat dua hal pokok yang ditemukan dalam penelitian ini. Pertama, digitalisasi tafsir menjadi menjadi ruh sentral dalam tafsirweb.com. Kedua, penerjemahan terhadap kitab-kitab tafsir mengarah pada demokratisasi atas sumber keagamaan dengan memunculkan kontestasi otoritas keagamaan yang merupakan implikasi internet atas otoritas agama.

\footnotetext{
${ }^{45}$ Pauline Hope Chong, Authority, ed. Heidi A. Campbell, Digital Religion: Understanding Religious Practice in New Media Worlds (New York: Routledge, 2013), 57.

${ }^{46}$ Najib Kailani dan Sunarwoto, "Televangelisme Islam Dalam Lanskap Otoritas Keagamaan Baru," dalam Ulama Dan Negara-Bangsa, ed. Noorhaidi Hasan (Yogyakarta: PusPIDeP, 2019), 182.

${ }^{47}$ Fadil Lukman, "Digital Hermeneutics and A New Face of The Quran Commentary: The Quran in Indonesian's Facebook", Al-Jami'ah: Journal of Islamic Studies 56 no.1 (2018). https://doi.org/10.14421/ ajis.2018.561.95-120.
} 


\section{DAFTAR PUSTAKA}

Abbas, Noorhan Hassan. "Quran 'Search for a Concept' Tool and Website" (n.d.): 171. Aminudin, Aminudin, Zamah Sari, and Setio Basuki. "Aplikasi Multimedia Interaktif Pada Pembelajaran Metode Tilawati Berbasis Web Responsive." JRST (Jurnal Riset Sains dan Teknologi)3, no. 1 (2019): 1-7. 10.30595/jrst.v3i1.3964.

As-Sa'idah, Millah Maryam. "Tafsir Alquran dalam website Muslim.or.id: studi pada sumber, metode dan corak” Diploma, UIN Sunan Gunung Djati Bandung, 2018. Accessed April 13, 2020. http://digilib.uinsgd.ac.id/14943/.

A.W. Munawir. Al-Munawir: Kamus Arab-Indonesia. 14th ed. Surabaya: Pustaka Progressif, 1997.

Fahrurroji, Moch. "Digitalizing Islamic Lectures: Islamic Apps and Religious Engagement in Contemporary Indonesia". Contemporary Islam 13 (2019):201215. https://doi.org/10.1007/s11562-018-0427-9.

Glenn Young. "Reading and Praying Online: The Continuity of Religion Online and Online Religion in Internet Chistianity." In Religion Online: Finding Faith on the Internet, edited by Lorne L. Dawson dan Douglas E. Cowan. New York: Routledge, 2004.

Heidi A. Campbell. Digital Religion: Understanding Religious Practice in New Media Worlds. Edited by Heidi A. Campbell. New York: Routledge, 2013.

Ikhwan, Munirul. "Challenging the State: Exegetical Translation in Opposition to the Official Religious Discourse of the Indonesian State." Journal of Qur'anic Studies 17 no.3 (2015): 121-157. https://www.euppublishing.com/doi/abs/10. 3366/jqs.2015.0214

Jalaluddin as-Suyuti. Al-Itqān Fì 'Ulūm al-Qur'Ān. 7th ed. Beirut: Dar al-Kotob alIlmiyah, 2019.

Jinan, Mutohharun, "Intervensi New Media dan Impersonalisasi Otoritas Keagamaan di Indonesia," Jurnal Komunikasi Islam 03 no. 02, (2013) : 321-348. https://doi.org/ 10.15642/jki.2013.3.2.\%25p

Lukman, Fadil, "Digital Hermeneutics and A New Face of The Quran Commentary: The Quran in Indonesian's Facebook", Al-Jami'ah: Journal of Islamic Studies 56 no.1 (2018). https://doi.org/10.14421/ ajis.2018.561.95-120

, "Tafsir Sosial Media Di Indonesia," Nun : Jurnal Studi Alquran Dan Tafsir Di Nusantara 2 no. 2 (2016): 117-139. 10.32495/nun.v2i2.59.

M Quraish Shihab. Membumikan Al-Qur'an. Bandung: Mizan, 1992.

Matthew B. Miles, and A. Michael Huberman. Qualitative Data Analysis: An Expanded Sourcebook. ii. Amerika Serikat: Sage Publications, n.d.

Moch Nur Ichwan. Negara, Kitab Suci, Dan Politik: Terjemah Resmi al-Qur'an Di Indonesia. Edited by Henri Chambert-Loir. Sadur: Sejarah Terjemahan di Indonesia dan Malaysia. Jakarta: Kepustakaan Populer Gramedia \& Ecole Française d'Extrême-Orient, 2009. 
Muhammad Saifullah. "Hermeneutika al-Qur'an Viertual: Kajian Atas Penafsiran Alquran Nadirsyah Hosen Di Facebook, Twitter, Telegram, Dan Website" Tesis, UIN Sunan Kalijaga, 2019.

Muhammad, Wildan Imaduddin. "Facebook Sebagai Media BaruTafsir Al-Qur'an Di Indonesia: Studi Atas Penafsiran Alquran Salman Harun," Maghza: Jurnal Ilmu Al-Qur'an dan Tafsir 2 no. 2 (2017): 69-80. https://doi.org/10.24090/ maghza.v2i2.1570.

Nafisatuzzahro. "Tafsir Al-Qur'an Audio Visual Cyber Media: Kajian Terhadap Studi al-Qur'an Dan Tafsir” Tesis, UIN Sunan Kalijaga, 2016.

Najib Kailani dan Sunarwoto. "Televangelisme Islam Dalam Lanskap Otoritas Keagamaan Baru." In Ulama Dan Negara-Bangsa, edited by Noorhaidi Hasan. Yogyakarta: PusPIDeP, 2019.

Nuralvi, Anis. “Metodologi Penafsiran Al-Qur'an Dalam Website Almanhaj.or.Id Dan Website Nadirhosen.Net” Diploma, UIN Sunan Gunung Djati Bandung, 2018. Accessed April 13, 2020. http://digilib.uinsgd.ac.id/12943/.

Pauline Hope Chong. Authority. Edited by Heidi A. Campbell. Digital Religion: Understanding Religious Practice in New Media Worlds. New York: Routledge, 2013.

Radzid, Amirul Ramzani, Mohd Sanusi Azmi, Intan Ermahani A. Jalil, Radzuan Nordin, Hairulnizam Mahdin, and Nur Atikah Arbain. "Kerangka Tashih Mushaf al-Qur'an Digital : Pendekatan Pengecaman Corak." Journal of Fatwa Management and Research (2018): 322-334.

Sanaky, Hujair A.H. "Metode Tafsir [Perkembangan Metode Tafsir Mengikuti Warna atau Corak Mufassirin]." Al-Mawarid 18 (2008): 263-284. http://jurnal.uii. ac.id/index.php/ JHI/article/view/157..

Sharon Lockyer. The Sage Encyclopedia of Qualitative Research Methods. Edited by Lisa M. Given. Vol. 1 dan 2. California: Sage Publications, 2008.

Wardani. Trend Perkembangan Pemikiran Kontemporer: Metodologi Tafsir al-Qur'an di Indonesia,. Banjarmasin: Kurnia Salam Semesta, 2017.,

Zakariah, Mohammed, Khan, Muhammed Khurram, Tayan, Omar, and Salah, Khaled, "Digital Quran Computing: Review, Classification, and Trend Analysis" Arab J Sci Eng 42 (2017): 3077-3102. https://doi.org/10.1007/s13369-017-2415-4

Sumber Internet:

"145300.Pdf," n.d. Accessed April 14, 2020. https://tafsirweb.com/wpcontent/uploads/ Kitab-Tafsir/04-Mukhtashar-Fii-Tafsiir-Nukhbah/145300.pdf.

“Al-Wajiz-Wahbah-Zuhaili.Pdf," n.d. Accessed April 14, 2020. https://tafsirweb.com/ wp-content/uploads/Kitab-Tafsir/14-al-Wajiz-Wahbah-Zuhaili/al-Wajiz Wahbah-Zuhaili.pdf. 
“Ar_Altafsir_Almaysir.Pdf," n.d. Accessed April 14, 2020. https://tafsirweb.com/wpcontent/uploads/Kitab-Tafsir/03-Tafsir-MuyassarNukhbah/ar_Altafsir_Almaysir.pdf.

“Ar_Zobdat_altafser.Pdf," n.d. Accessed April 14, 2020. https://tafsirweb.com/wpcontent/uploads/Kitab-Tafsir/06-Zubdat-at-Tafsir/ar_Zobdat_altafser.pdf.

"Digital Islamic Law: Purpose and Prospects - ProQuest." Accessed October 6, 2020. https://search.proquest.com/openview/0cef2e8eef07d6864c6bd48991e0729a/1? pq-origsite $=$ gscholar \&cbl $=48662$.

"Halaman Tafsirweb." Accessed April 13, 2020. https://tafsirweb.com/halaman.

"Halaman 5 - Tafsir Al-Qur'an Muhammadiyah." Halaman 5 - Tafsir Al-Qur'an Muhammadiyah. Accessed October 7, 2020. http://m.muhammadiyah.or.id/id/ 5-content-190-det-tafsir-alquran.html.

“Tafsir Surat Al-Baqarah Ayat 2." Last modified January 31, 2020. Accessed October 6, 2020. https://islam.nu.or.id/post/read/116041/tafsir-surat-al-baqarah-ayat-2. 